Supporting Information to:

\title{
Solid-Supported Porphyrins Useful for the Synthesis of Conjugates with Oligomeric Biomolecules
}

\author{
Satish Jadhav, ${ }^{\mathrm{a}}$ Cheng-Bin Yim, ${ }^{\mathrm{b}}$ Johan Rajander, ${ }^{\mathrm{b}}$ Tove J. Grönroos, ${ }^{\mathrm{c}, \mathrm{d}}$ Olof Solin ${ }^{\mathrm{a}, \mathrm{c}}$ and Pasi \\ Virta $^{\mathrm{a} *}$ \\ ${ }^{a}$ Department of Chemistry, University of Turku, FI-20014 Turku, Finland \\ ${ }^{b}$ Turku PET Centre, Åbo Akademi University, FI-20520 Turku, Finland \\ ${ }^{c}$ Turku PET Centre, University of Turku, FI-20520 Turku, Finland \\ ${ }^{d}$ Medicity Research Laboratory, University of Turku, FI-20520 Turku, Finland
}

\section{Contents}

Figures S1-2. ${ }^{1} \mathrm{H}$ NMR $\left(500 \mathrm{MHz}, \mathrm{CDCl}_{3}\right)$ and ${ }^{13} \mathrm{C}\left(125 \mathrm{MHz}, \mathrm{CDCl}_{3}\right)$ spectra of 2

Figures S3-4. ${ }^{1} \mathrm{H}$ NMR $\left(500 \mathrm{MHz}, \mathrm{CDCl}_{3}\right)$ and ${ }^{13} \mathrm{C}\left(125 \mathrm{MHz}, \mathrm{CDCl}_{3}\right)$ spectra of meso-tris(4- $N$-pyridyl)(4-methoxycarbonylphenyl)porphyrin $\quad$ S3

Figures S5-6. ${ }^{1} \mathrm{H}$ NMR $\left(500 \mathrm{MHz}, \mathrm{CDCl}_{3}\right)$ and ${ }^{13} \mathrm{C}\left(125 \mathrm{MHz}, \mathrm{CDCl}_{3}\right)$ spectra of 3

Figures S7-9. ${ }^{1} \mathrm{H}$ NMR (500 MHz, DMSO- $\mathrm{d}_{6}$ ) spectra of 4

Figures S10-11. ${ }^{13} \mathrm{C}\left(125 \mathrm{MHz}, \mathrm{DMSO}-\mathrm{d}_{6}\right)$ spectra of $4 \quad$ S6

$\begin{array}{ll}\text { Figure S12. HSQC spectrum of } 4 & \text { S7 }\end{array}$

$\begin{array}{ll}\text { Figures S13. MS (ESI-TOF) monitoring of the succinylation of } \mathbf{3} \text { and } \mathbf{4} & \text { S7 }\end{array}$

$\begin{array}{ll}\text { Figures S14. RP HPLC profile and MS (ESI-TOF) spectrum of } 7 & \text { S8 }\end{array}$

$\begin{array}{ll}\text { Figure S15. RP HPLC profile and MS (ESI-TOF) spectrum of } 8 & \text { S8 }\end{array}$

Figure S16. RP HPLC profile and MS (ESI-TOF) spectrum of $9 \quad$ S9

Figure S17. RP HPLC profile and MS (ESI-TOF) spectrum of $10 \quad$ S10

Figure S18. RP HPLC profile and MS (ESI-TOF) spectrum of $\mathbf{1 1} \quad$ S10

$\begin{array}{ll}\text { Figure S19. RP HPLC profile and MS (ESI-TOF) spectrum of } \mathbf{1 2} & \text { S11 }\end{array}$

$\begin{array}{ll}\text { Figure S20. RP HPLC profile and MS (ESI-TOF) spectrum of } \mathbf{1 3} & \text { S11 }\end{array}$

Figure S21. RP HPLC and MS (ESI-TOF) monitoring of the SPAAC conjugation between 14 and 19 and of the post-synthetic protecting groupo manipulation of the HA moiety

Table S1: Cell binding evaluation of ${ }^{64} \mathrm{Cu}-$ labeled PyCPP-HA $\left(\mathbf{1 5}\left[{ }^{64} \mathrm{Cu}\right]\right) \quad$ S13 


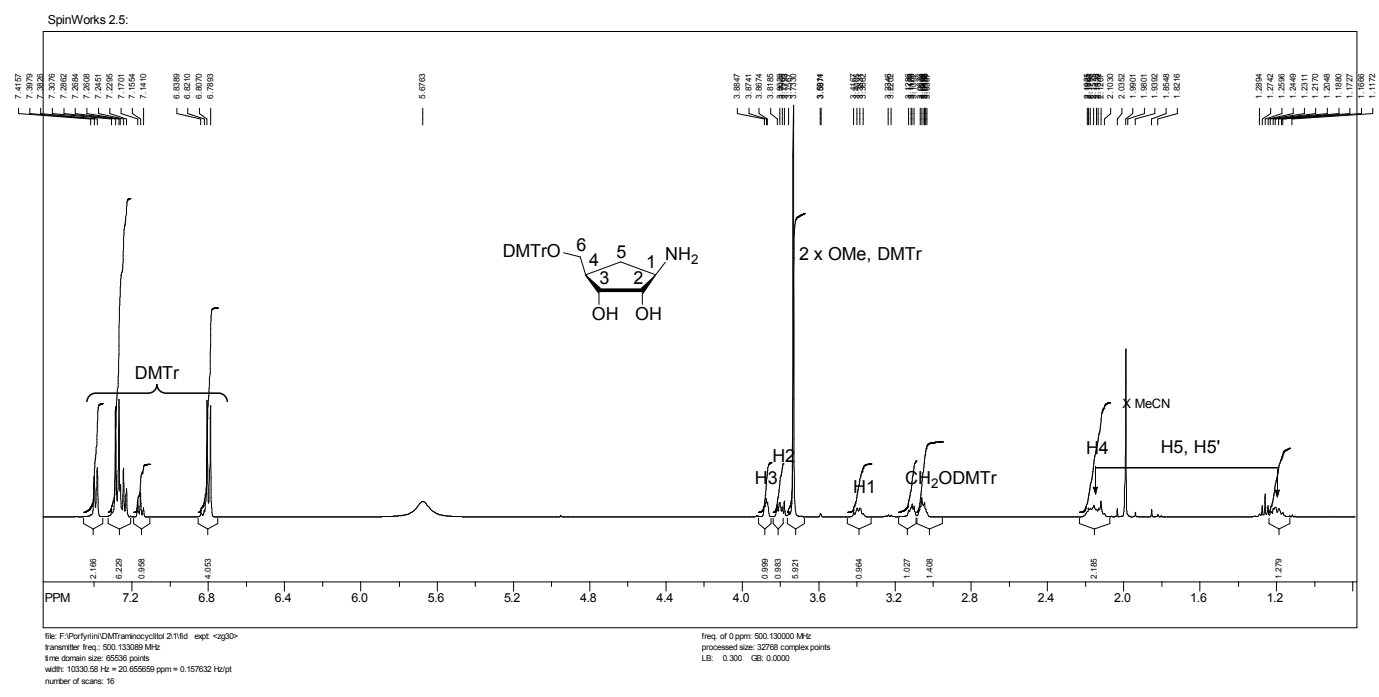

Figure S1. ${ }^{1} \mathrm{H}$ NMR $\left(500 \mathrm{MHz}, \mathrm{CDCl}_{3}\right)$ spectrum of 2

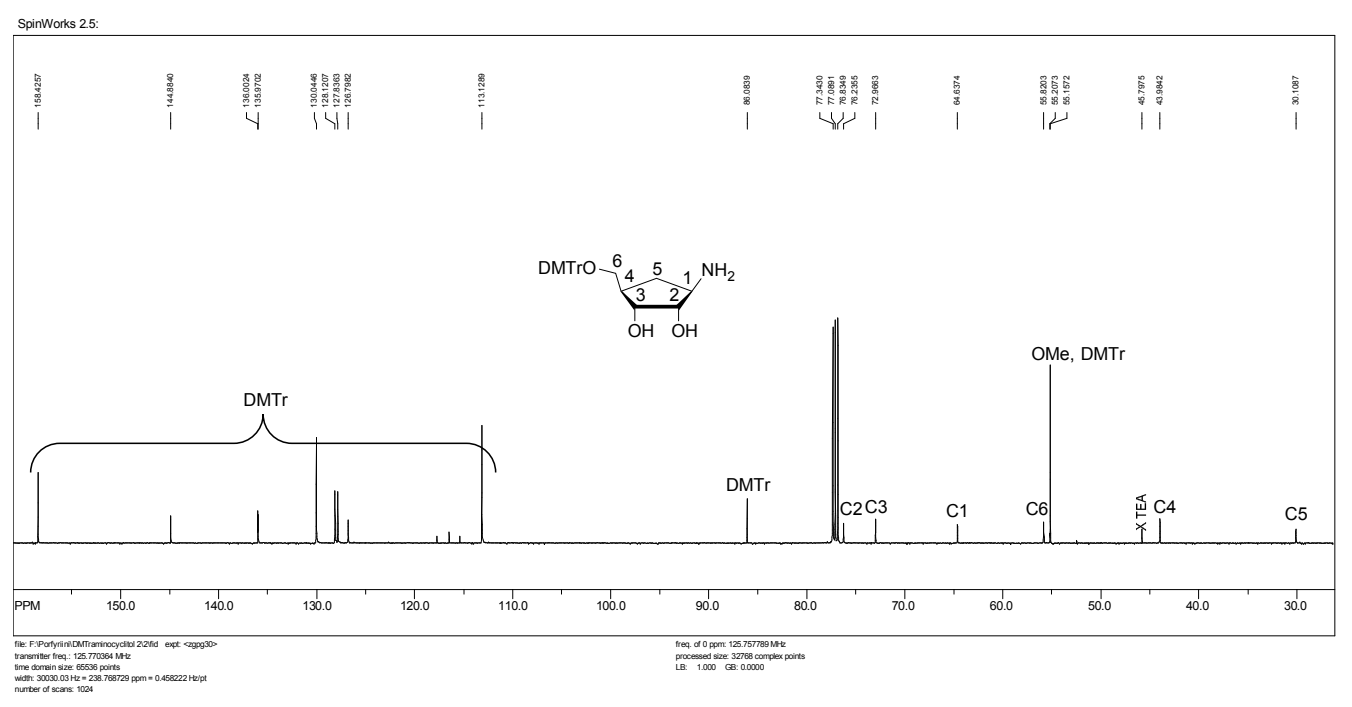

Figure S2. ${ }^{13} \mathrm{C}\left(125 \mathrm{MHz}, \mathrm{CDCl}_{3}\right)$ spectrum of 2 


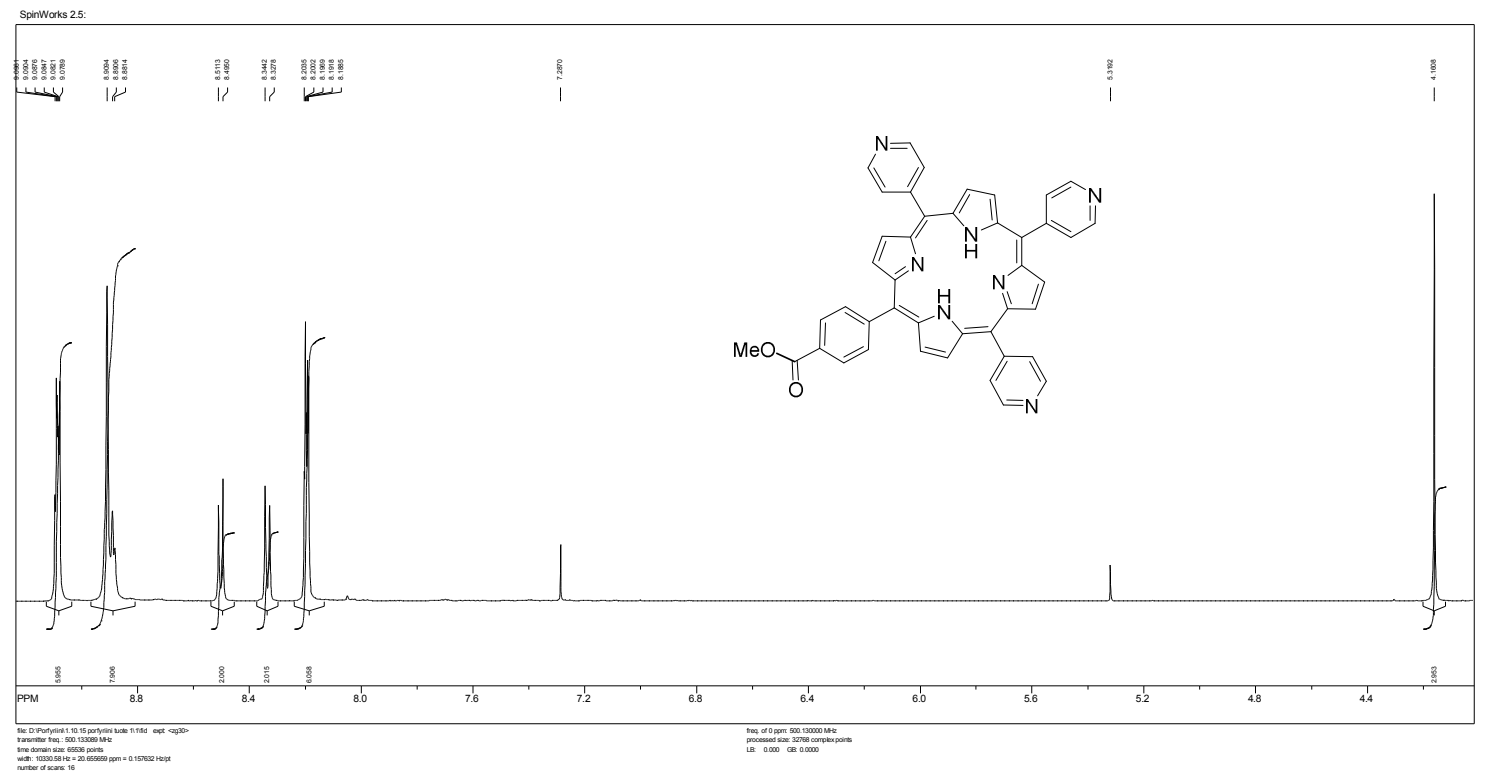

Figure S3. ${ }^{1} \mathrm{H}$ NMR $\left(500 \mathrm{MHz}, \mathrm{CDCl}_{3}\right)$ spectrum of meso-tris(4- $N$-pyridyl)(4methoxycarbonylphenyl)porphyrin (published previously by Li, H. et al ${ }^{1}$ ).

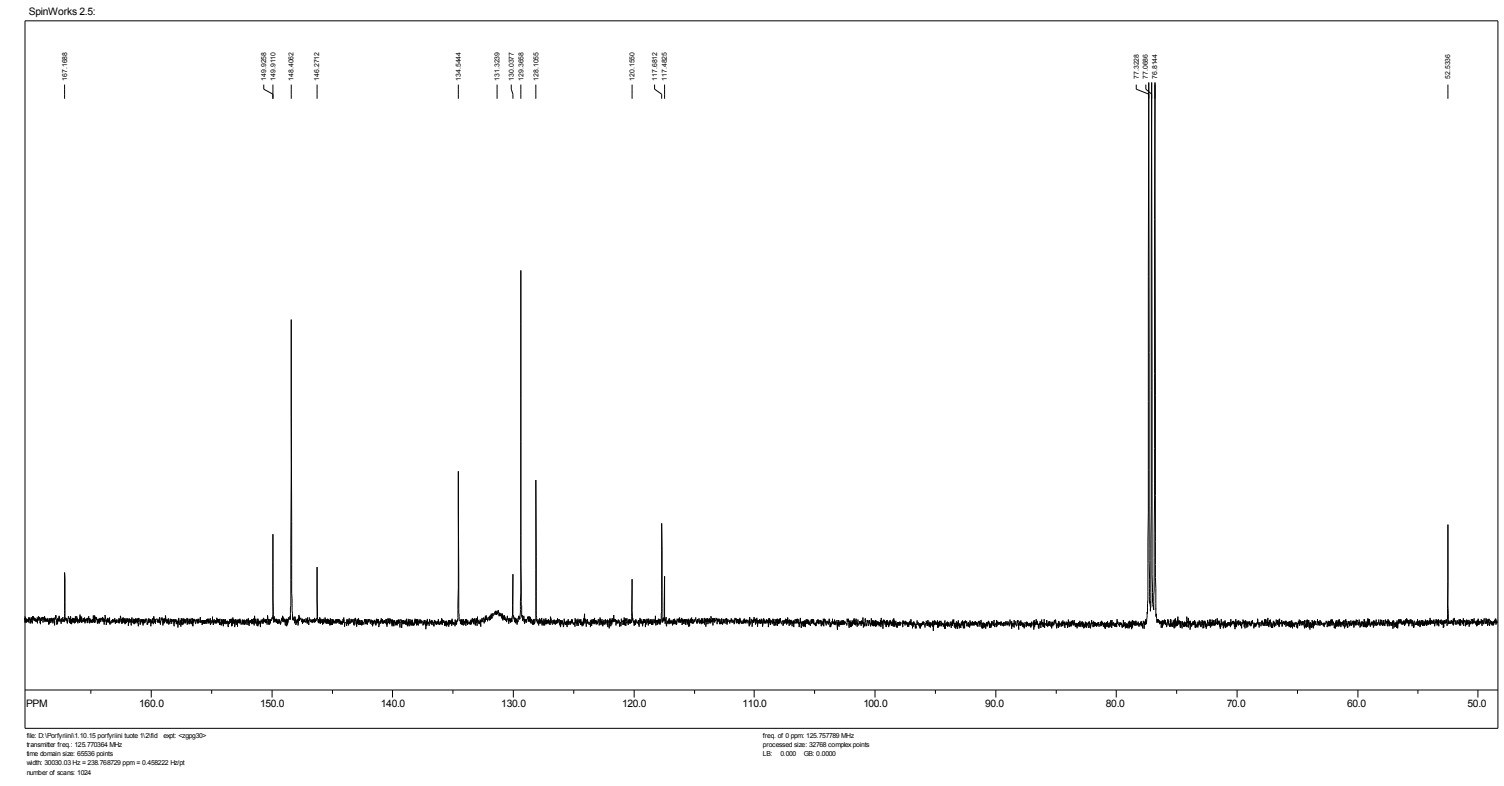

Figure $\mathbf{S 4} .{ }^{13} \mathrm{C}\left(125 \mathrm{MHz}, \mathrm{CDCl}_{3}\right)$ spectrum of meso-tris(4- $\mathrm{N}$-pyridyl)(4methoxycarbonylphenyl)porphyrin (published previously by Li, H. et al ${ }^{1}$ ). 


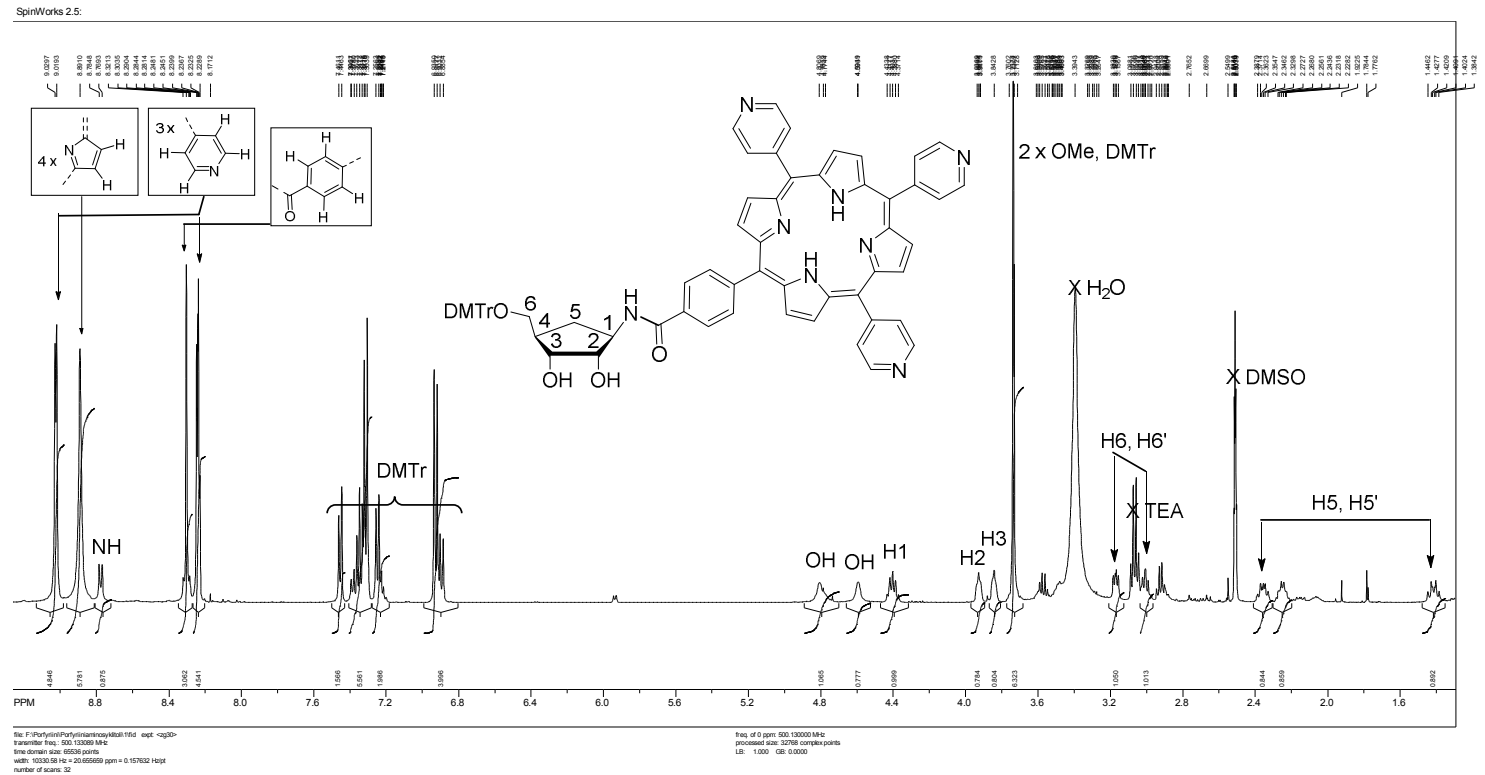

Figure S5. ${ }^{1} \mathrm{H}$ NMR $\left(500 \mathrm{MHz}, \mathrm{CDCl}_{3}\right)$ spectrum of 3.

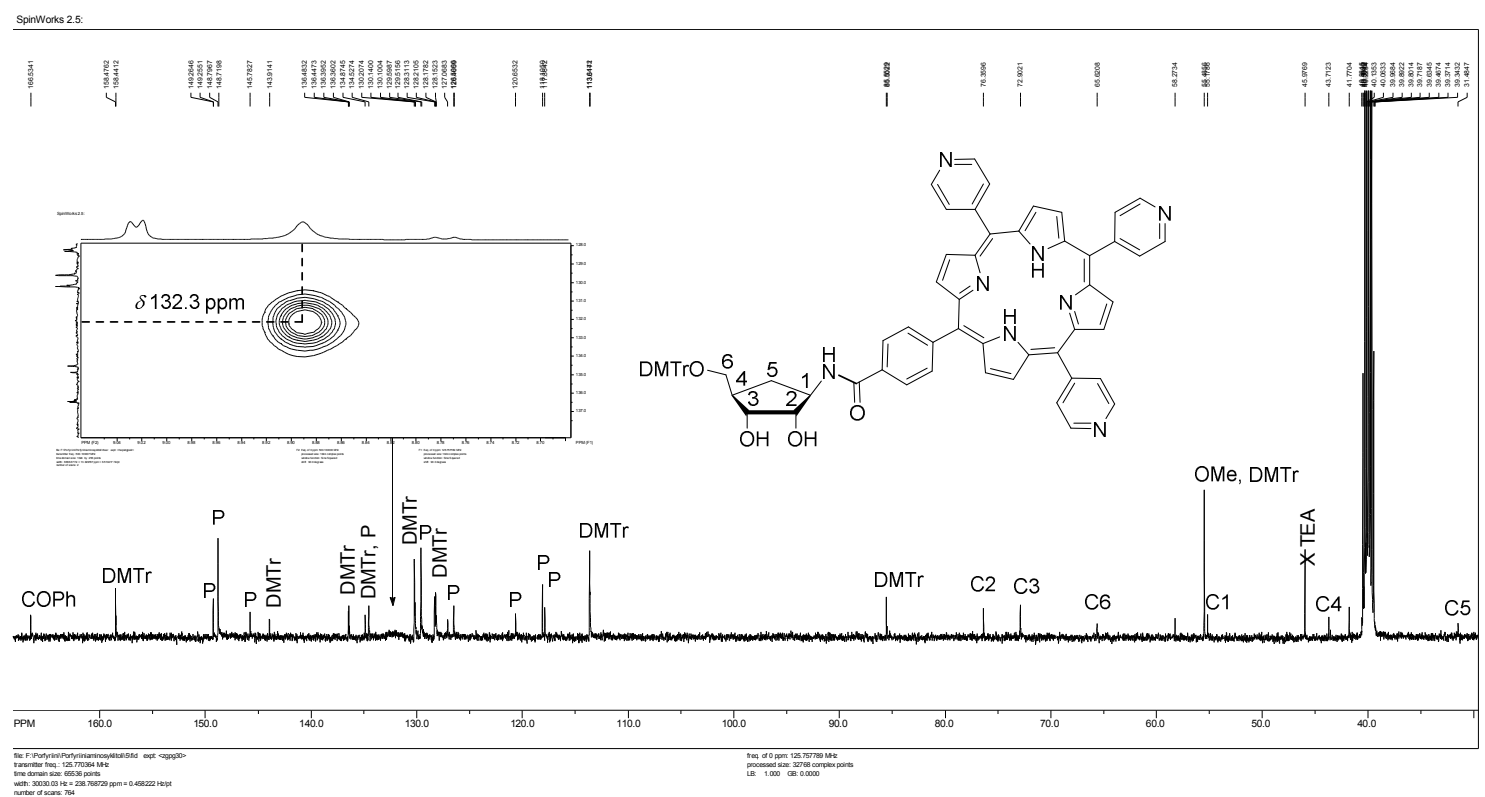

Figure S6. ${ }^{13} \mathrm{C}\left(125 \mathrm{MHz}, \mathrm{CDCl}_{3}\right)$ spectrum of 3 . 


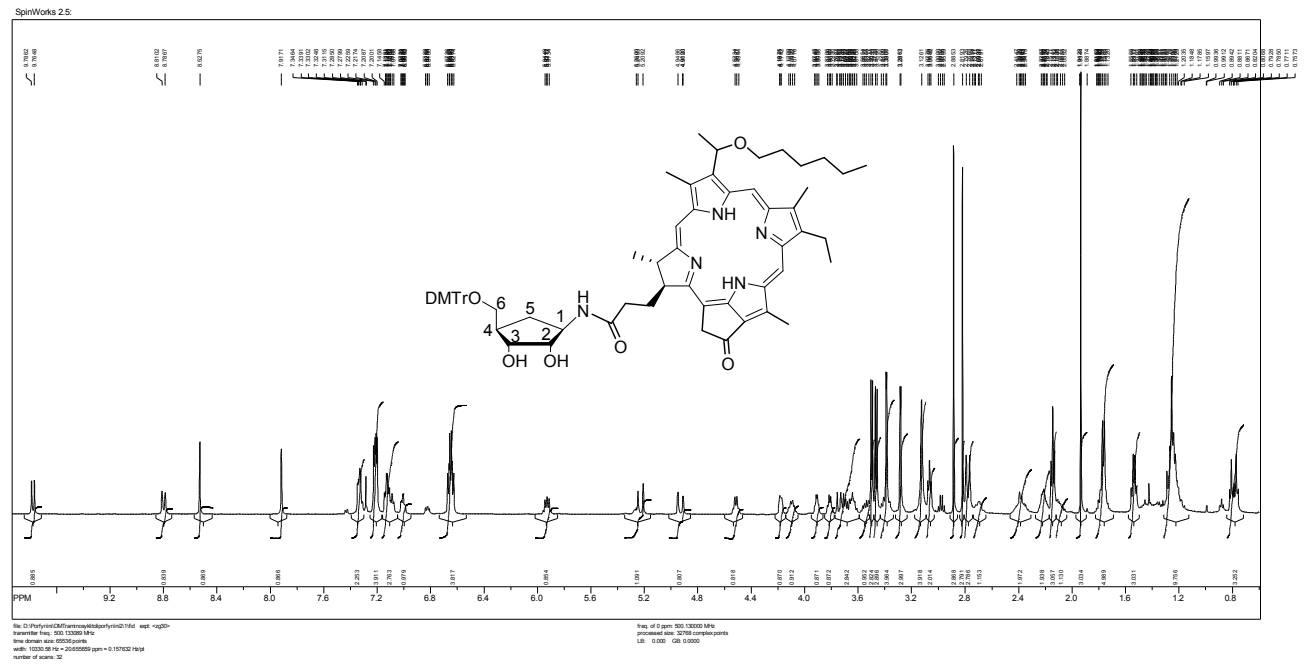

Figure S7. ${ }^{1} \mathrm{H}$ NMR $\left(500 \mathrm{MHz}, \mathrm{DMSO}-\mathrm{d}_{6}\right)$ spectrum of 4.

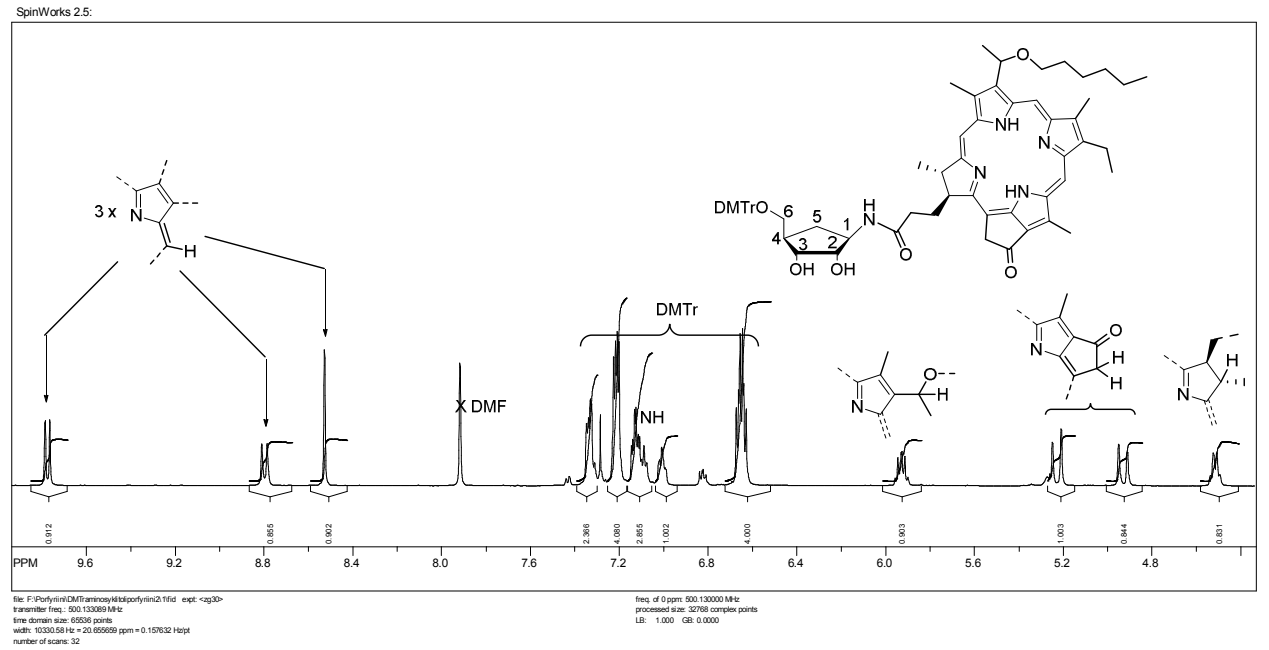

Figure S8. ${ }^{1} \mathrm{H}$ NMR (500 MHz, DMSO-d ${ }_{6}$ ) spectrum of 4.

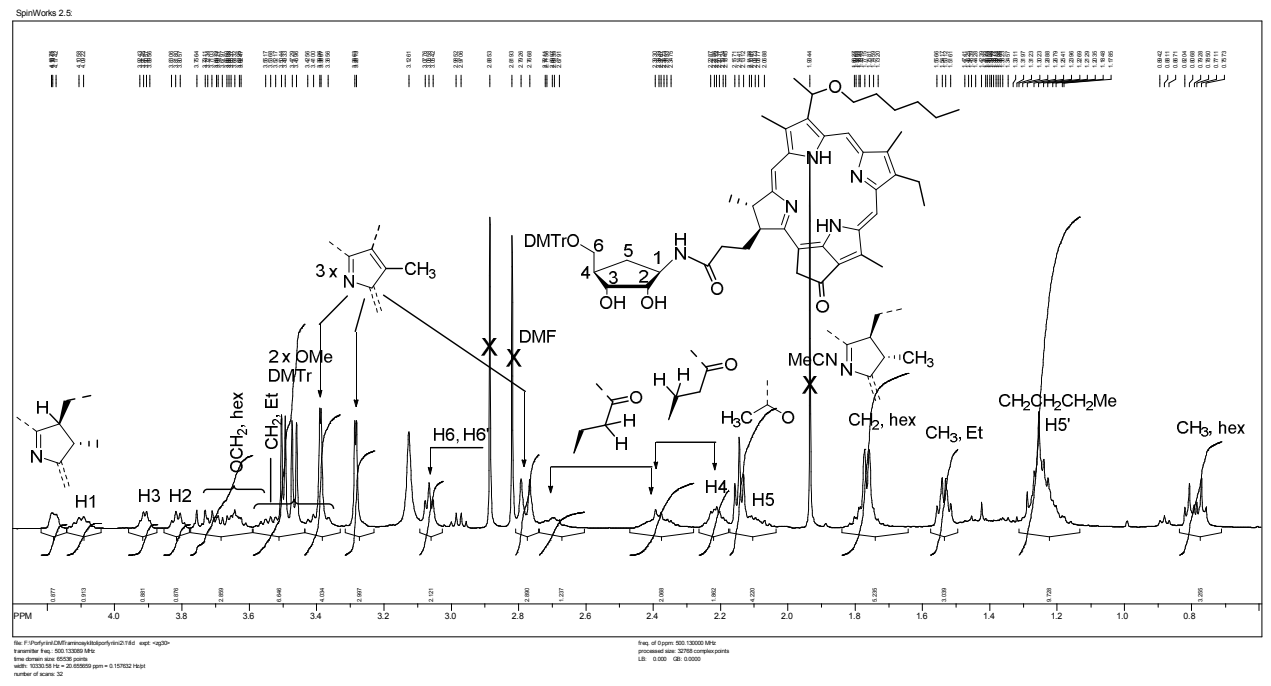

Figure S9. ${ }^{1} \mathrm{H}$ NMR $\left(500 \mathrm{MHz}, \mathrm{DMSO}-\mathrm{d}_{6}\right)$ spectrum of 4. 


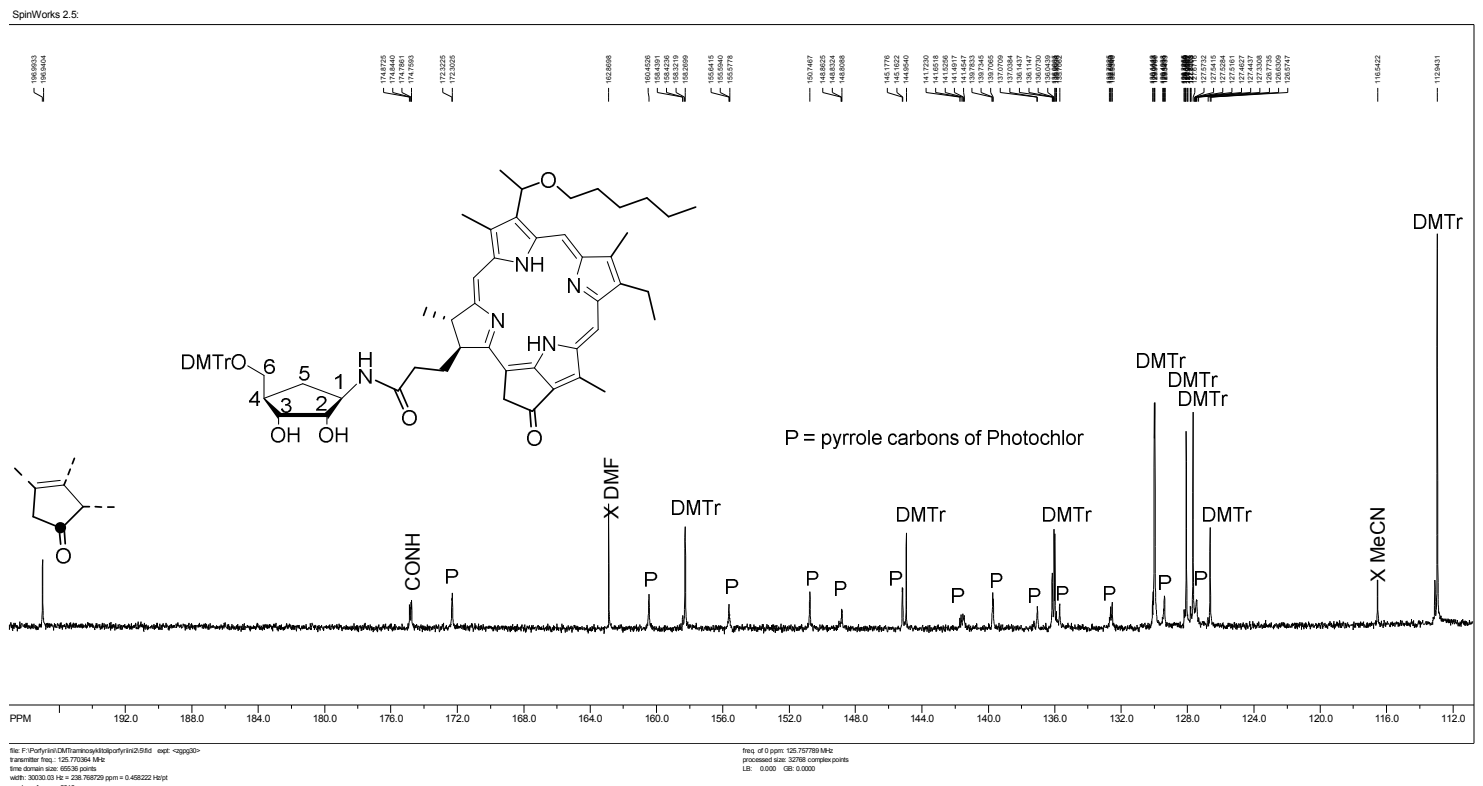

Figure S10. ${ }^{13} \mathrm{C}\left(125 \mathrm{MHz}, \mathrm{DMSO}-\mathrm{d}_{6}\right)$ spectrum of 4.

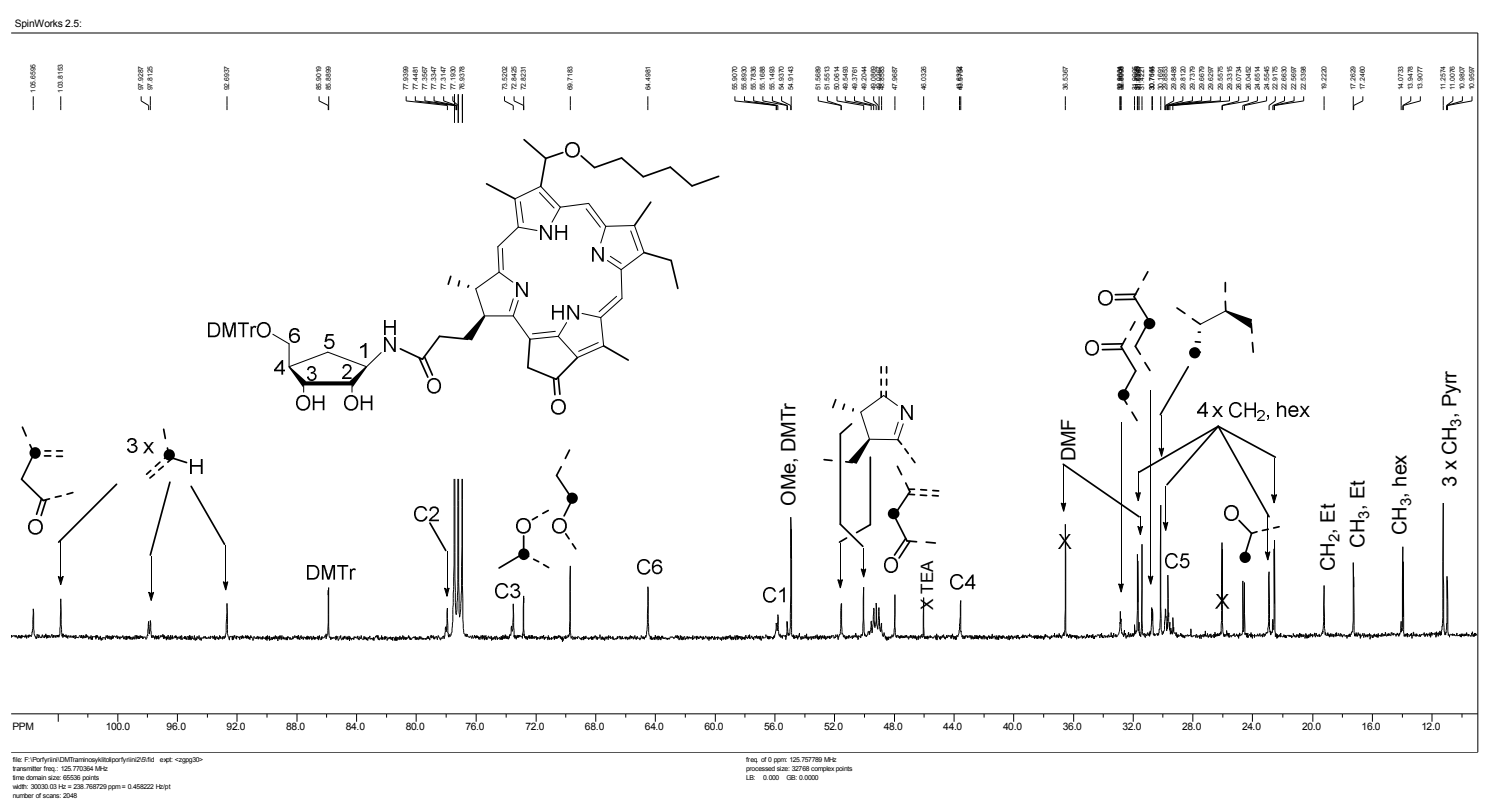

Figure S11. ${ }^{13} \mathrm{C}\left(125 \mathrm{MHz}, \mathrm{DMSO}-\mathrm{d}_{6}\right)$ spectrum of 4. 


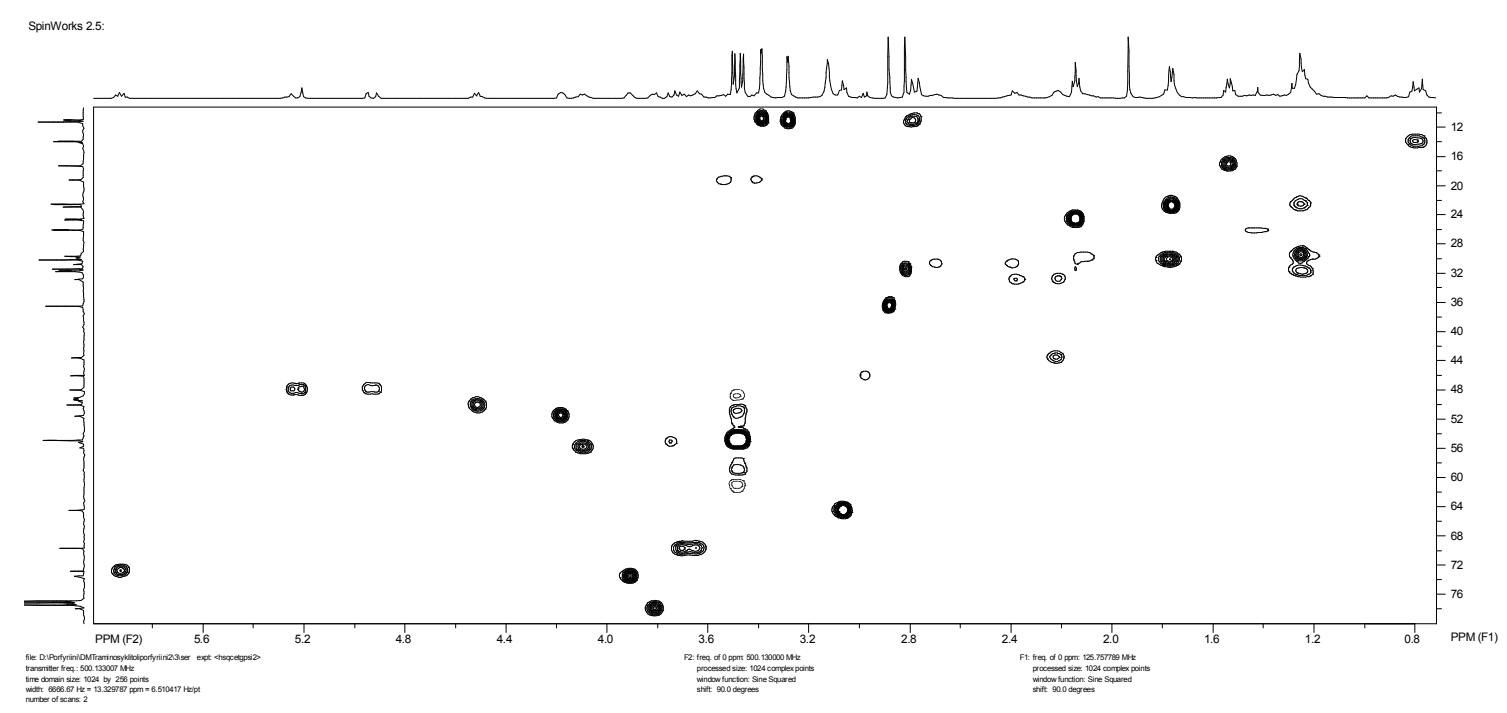

Figure S12. HSQC spectrum of 4.
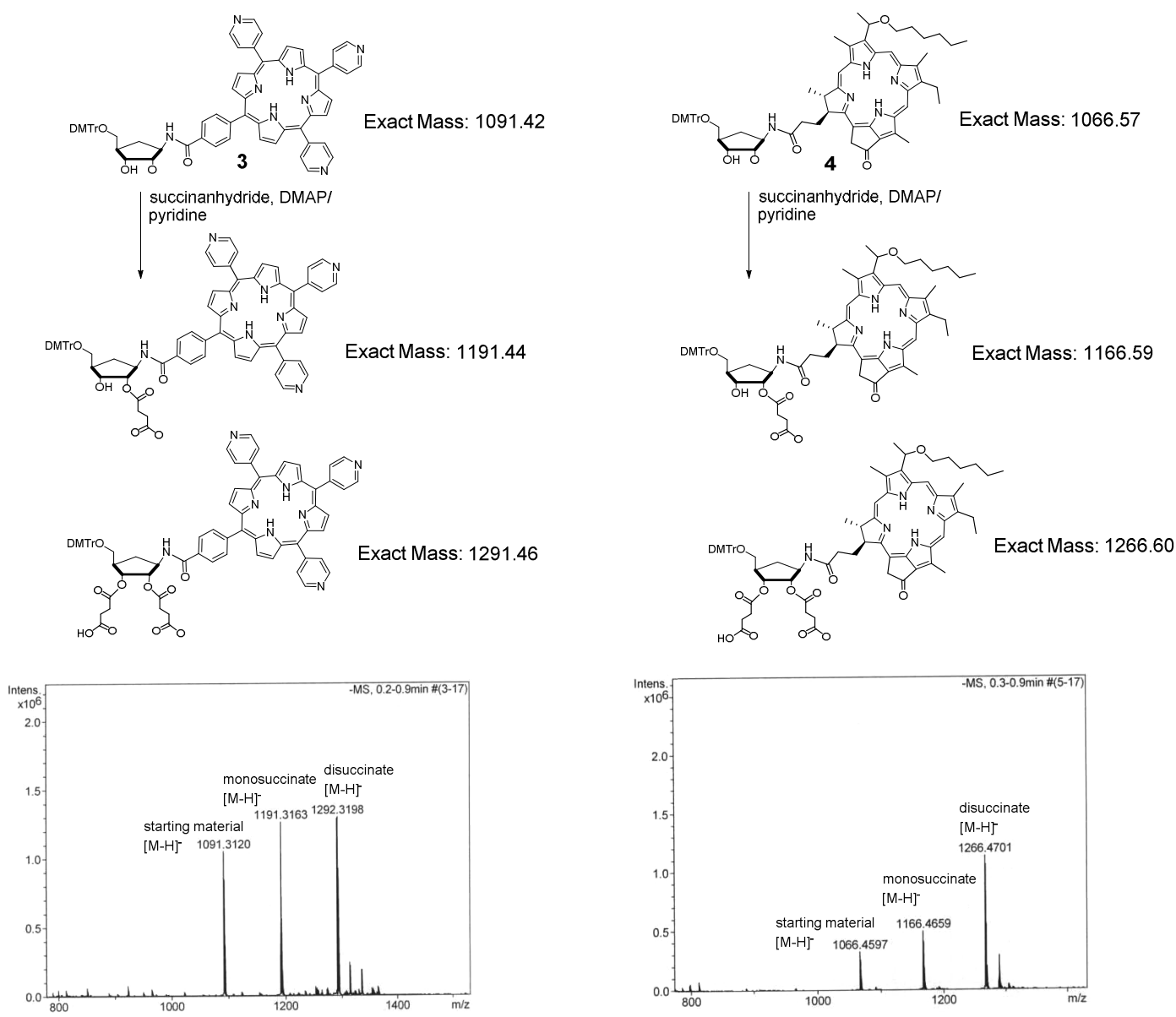

Figure S13. MS (ESI-TOF) monitoring of the succinylation of 3 and 4 (the mixtures prior to the immobilization to LCAA-CPG support) 

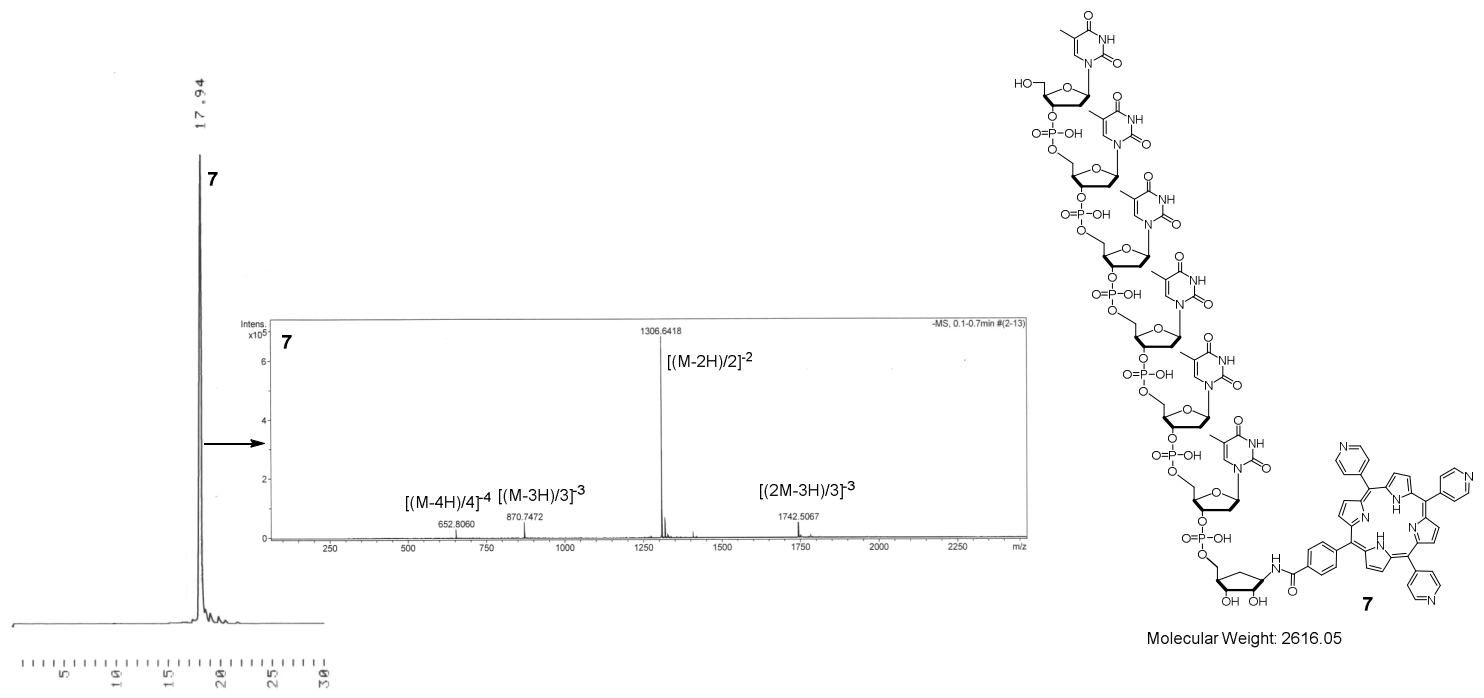

Figure S14. RP HPLC profile of the crude product (7) mixture and MS (ESI-TOF) spectrum of the homogenized product (7). RP HPLC conditions: an analytical RP HPLC column (C-18, $250 \times 4.6$ $\mathrm{mm}, 5 \mu \mathrm{m}$ ), a linear gradient from 20 to $90 \% \mathrm{MeCN}$ in $0.1 \mathrm{~mol} \mathrm{~L}^{-1}$ triethylammonium acetate over 25 $\min , \lambda=400 \mathrm{~nm}$.

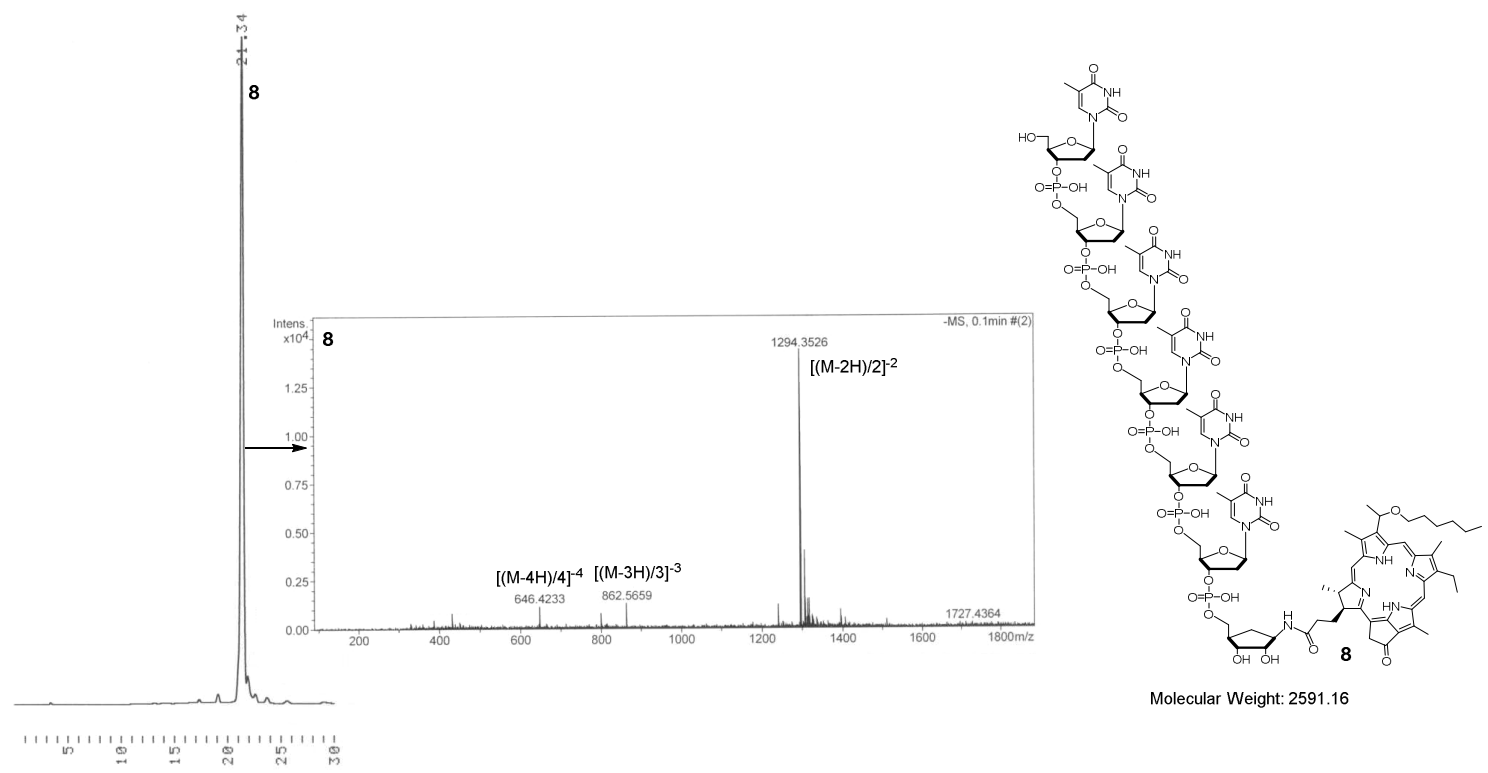

Figure S15. RP HPLC profile of the crude product (8) mixture and MS (ESI-TOF) spectrum of the homogenized product (8). RP HPLC conditions: an analytical RP HPLC column $(\mathrm{C}-18,250 \times 4.6$ $\mathrm{mm}, 5 \mu \mathrm{m}$ ), a linear gradient from 20 to $90 \% \mathrm{MeCN}$ in $0.1 \mathrm{~mol} \mathrm{~L}^{-1}$ triethylammonium acetate over 25 $\min , \lambda=400 \mathrm{~nm}$. 


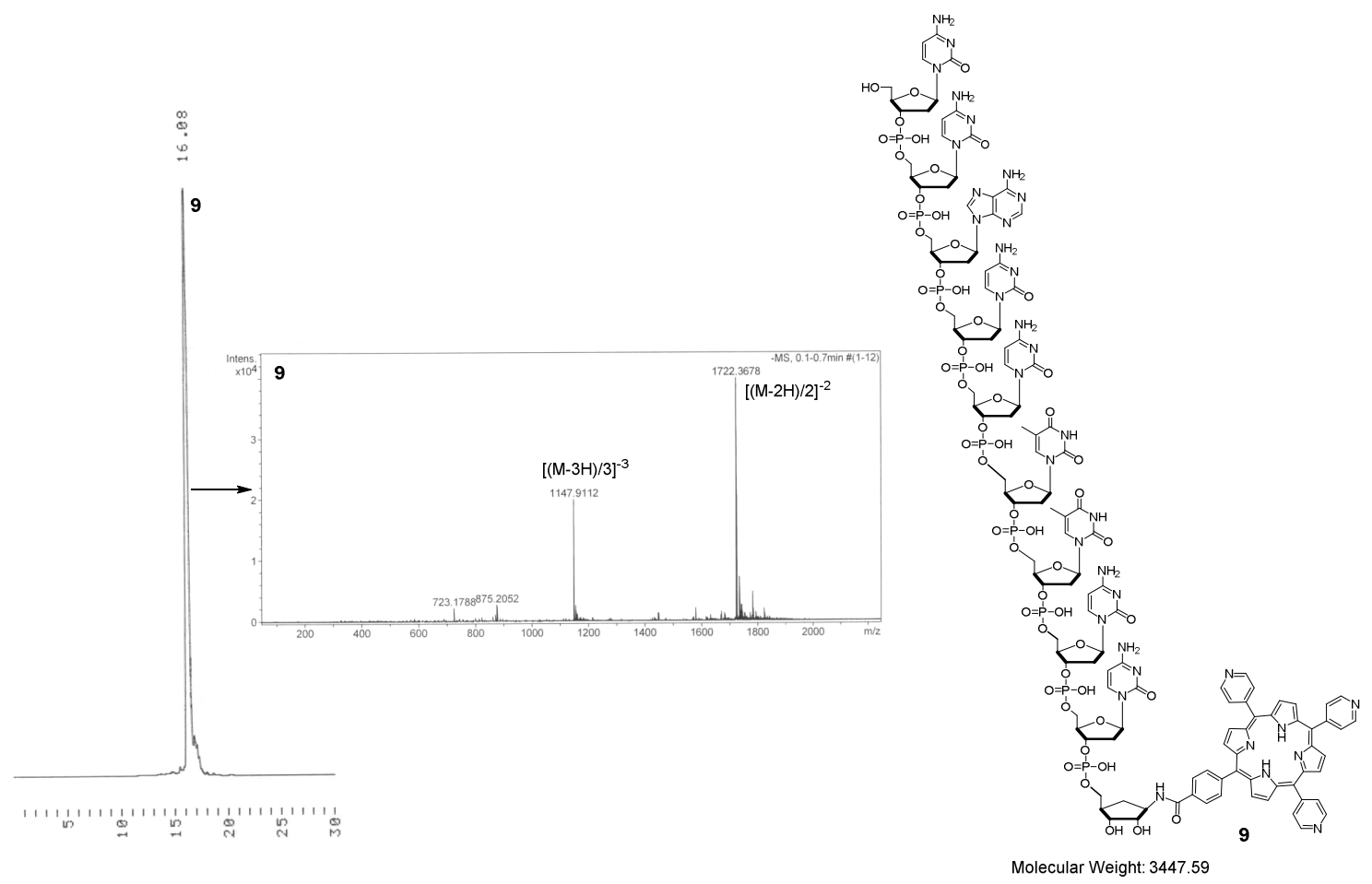

Figure S16. RP HPLC profile of the crude product (9) mixture and MS (ESI-TOF) spectrum of the homogenized product (9). RP HPLC conditions: an analytical RP HPLC column (C-18, $250 \times 4.6$ $\mathrm{mm}, 5 \mu \mathrm{m})$, a linear gradient from 20 to $90 \% \mathrm{MeCN}$ in $0.1 \mathrm{~mol} \mathrm{~L}^{-1}$ triethylammonium acetate over 25 $\min , \lambda=400 \mathrm{~nm}$. 


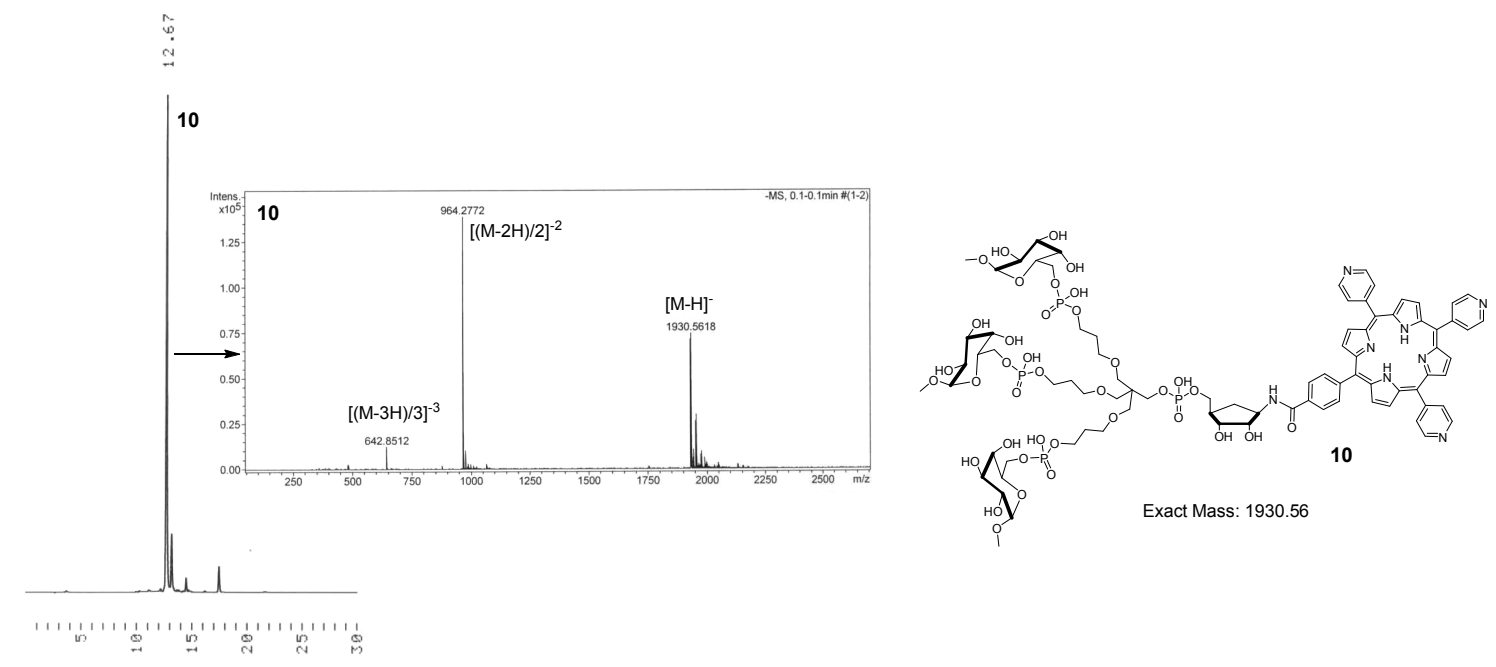

Figure S17. RP HPLC profile of the crude product (10) mixture and MS (ESI-TOF) spectrum of the homogenized product (10). RP HPLC conditions: an analytical RP HPLC column (C-18, $250 \times 4.6$ $\mathrm{mm}, 5 \mu \mathrm{m}$ ), a linear gradient from 20 to $90 \% \mathrm{MeCN}$ in $0.1 \mathrm{~mol} \mathrm{~L}^{-1}$ triethylammonium acetate over 25 $\min , \lambda=400 \mathrm{~nm}$.

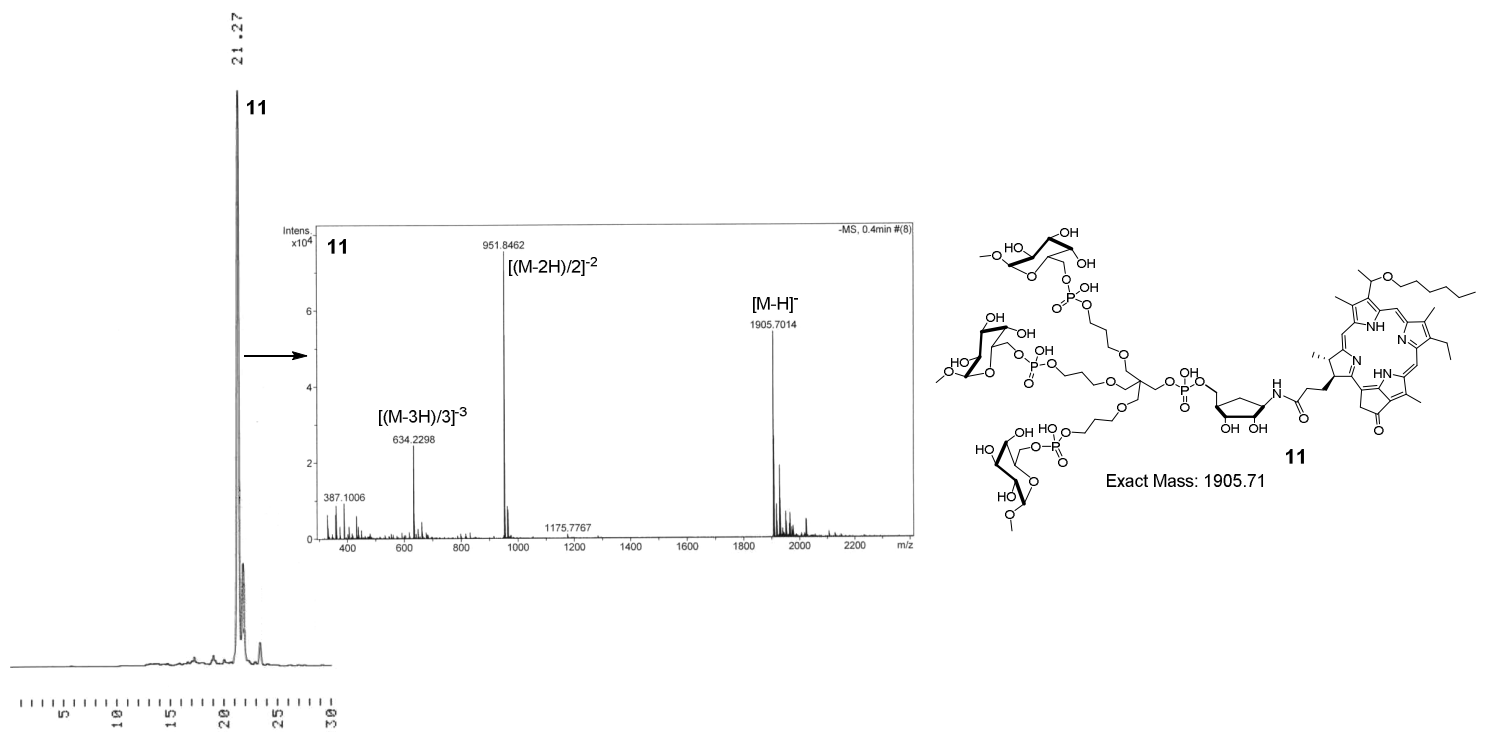

Figure S18. RP HPLC profile of the crude product (11) mixture and MS (ESI-TOF) spectrum of the homogenized product (11). RP HPLC conditions: an analytical RP HPLC column (C-18, $250 \times 4.6$ $\mathrm{mm}, 5 \mu \mathrm{m}$ ), a linear gradient from 20 to $90 \% \mathrm{MeCN}$ in $0.1 \mathrm{~mol} \mathrm{~L}^{-1}$ triethylammonium acetate over 25 $\min , \lambda=400 \mathrm{~nm}$. 

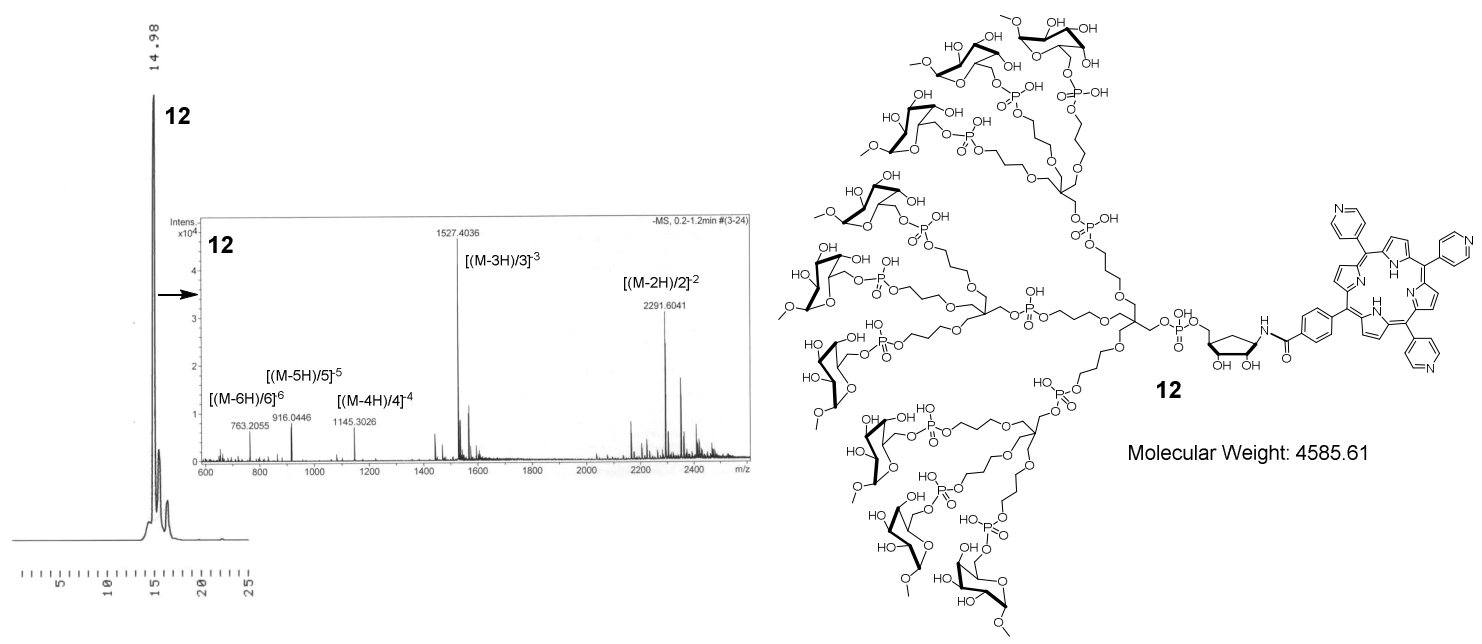

Figure S19. RP HPLC profile of the crude product (12) mixture and MS (ESI-TOF) spectrum of the homogenized product (12). RP HPLC conditions: an analytical RP HPLC column $(\mathrm{C}-18,250 \times 4.6$ $\mathrm{mm}, 5 \mu \mathrm{m}$ ), a linear gradient from 20 to $90 \% \mathrm{MeCN}$ in $0.1 \mathrm{~mol} \mathrm{~L}^{-1}$ triethylammonium acetate over 25 $\min , \lambda=400 \mathrm{~nm}$.

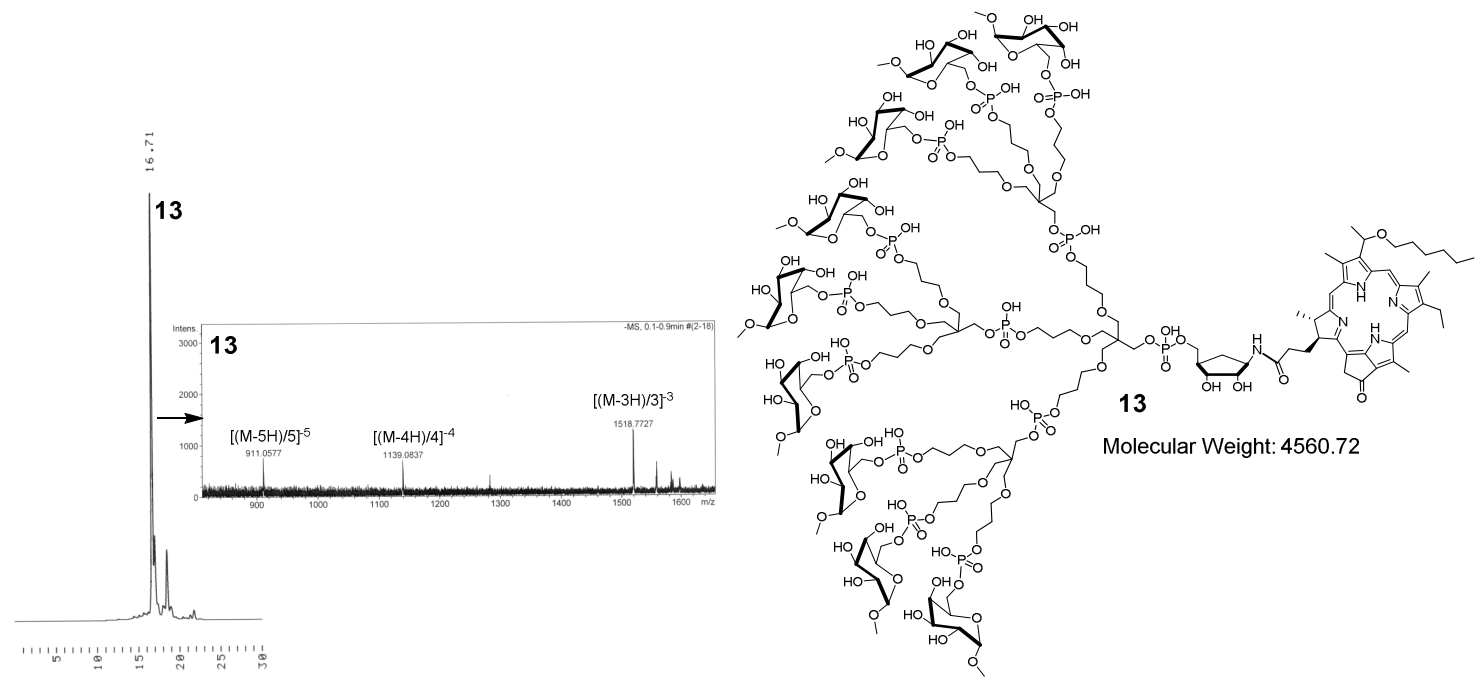

Figure S20. RP HPLC profile of the crude product (13) mixture and MS (ESI-TOF) spectrum of the homogenized product (13). RP HPLC conditions: an analytical RP HPLC column (C-18, $250 \times 4.6$ $\mathrm{mm}, 5 \mu \mathrm{m}$ ), a linear gradient from 20 to $90 \% \mathrm{MeCN}$ in $0.1 \mathrm{~mol} \mathrm{~L}^{-1}$ triethylammonium acetate over 25 $\min , \lambda=400 \mathrm{~nm}$ 


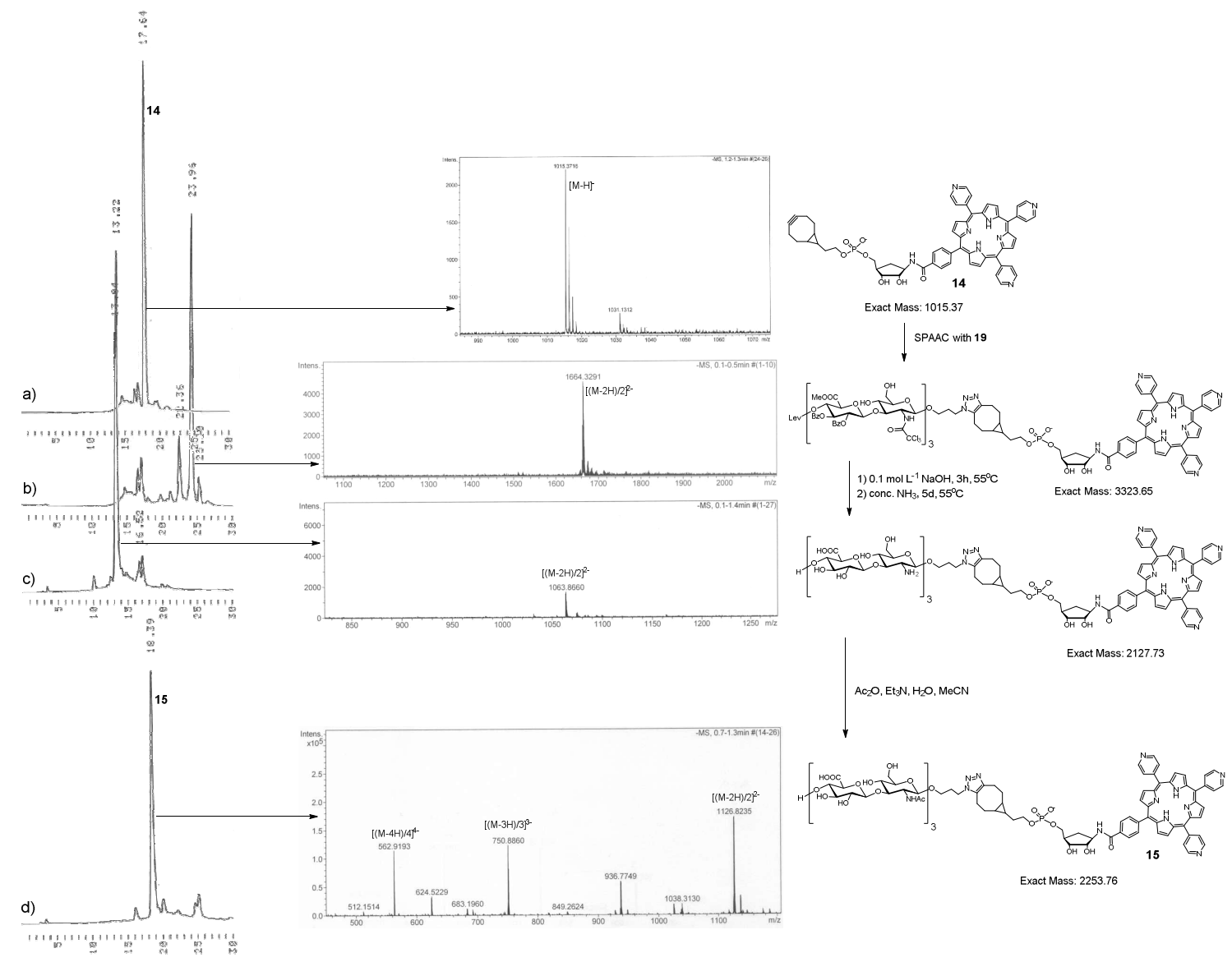

Figure S21. RP HPLC and MS (ESI-TOF) monitoring of the SPAAC-conjugation between 14 and 19 and of the post-synthetic protecting group manipulation of the HA moiety. RP HPLC conditions: an analytical RP HPLC column $(\mathrm{C}-18,250 \times 4.6 \mathrm{~mm}, 5 \mu \mathrm{m})$, a linear gradient from 20 to $90 \% \mathrm{MeCN}$ (ac) or from 20 to $60 \% \mathrm{MeCN}$ (d) in $0.1 \mathrm{~mol} \mathrm{~L}^{-1}$ triethylammonium acetate over $25 \mathrm{~min}, \lambda=400 \mathrm{~nm}$. 
Table S1: Cell binding evaluation of ${ }^{64} \mathrm{Cu}$-labeled PyCPP-HA conjugate $\left(15\left[{ }^{64} \mathrm{Cu}\right]\right)$ with MDAMB-231 and MCF-7 tumor cell lines.

\begin{tabular}{|c|c|c|c|c|}
\hline \multirow{2}{*}{ Competitor (nM) } & \multicolumn{3}{|c|}{ MDA-MB-231 } & \multirow{2}{*}{$\begin{array}{c}\text { MCF-7 } \\
60 \min (n=2)\end{array}$} \\
\hline & $30 \min (n=3)$ & $60 \min (n=2)$ & $120 \min (n=2)$ & \\
\hline 0 & $10.4 \pm 0.3$ & $9.3 \pm 0.9$ & $10.4 \pm 0.5$ & $10.5 \pm 0.6$ \\
\hline 2 & $9.9 \pm 1.0$ & $8.7 \pm 0.3$ & $9.9 \pm 0.3$ & $9.6 \pm 0.7$ \\
\hline 20 & $9.6 \pm 0.8$ & $8.6 \pm 0.2$ & $8.7 \pm 0.3$ & $9.5 \pm 0.3$ \\
\hline 200 & $8.0 \pm 0.6$ & $7.0 \pm 0.1$ & $6.6 \pm 0.2$ & $7.9 \pm 1.0$ \\
\hline
\end{tabular}

Receptor binding properties of $\mathbf{1 5}\left[{ }^{64} \mathrm{Cu}\right]$ was determined from in vitro incubation experiments with two tumor cell lines in the presence of increasing concentration of unlabeled PyCPP-HA conjugate (15) as the competitor. Values are expressed as ratio (\%) of cell-bound radioactivity to the applied total radioactivity (mean \pm SD).

(1) Li, H., Fedorova, O. S., Trumble, W. R., Fletcher, T. R., Czuchajowski, L. (1997) Site-Specific Photomodification of DNA by Porphyrin-Oligonucleotide Conjugates Synthesized via a Solid Phase H- phosphonate Approach. Bioconjugate Chem. 8, 49-56. 